\title{
PROBLEM OTENTITAS HADITS (Kritik Musthafa Azami terhadap Pemikiran Ignaz Goldziher)
}

\author{
Abdul Rohman \\ Universitas Darussalam (UNIDA) Gontor Ponorogo Jawa Timur \\ ilmanhaq9@gmail.com \\ Amir Sahidin \\ Universitas Darussalam (UNIDA) Gontor Ponorogo Jawa Timur \\ amirsahidin42003@mhs.unida.gontor.ac.id \\ Yusuf Al Manaanu \\ Universitas Darussalam (UNIDA) Gontor Ponorogo Jawa Timur \\ yusuf.almanaanu@gmail.com \\ Muhammad Nasiruddin \\ Institut Agama Islam Syarifuddin (IAIS) Lumajang Jawa Timur \\ nasiruddinmuhammad4@gmail.com
}

\begin{abstract}
Abstrak
Makalah ini akan membahas mengenai keraguan Ignaz Goldziher atas keotentikan hadits Nabi. Dengan metodologi kritik historis dia meragukan keotentikan hadits. Pandangan ini tentunya membuat kegelisahan bagi sarjana Muslim, karena sudah menjadi kesepakatan bahwa hadits adalah sumber hukum Islam kedua. Untuk menjawab keraguan tersebut Musthafa Azami melakukan kritik terhadap pemikirannya. Oleh karenanya penulis akan membahas tentang kritik Musthafa Azami terhadap pemikiran Ignaz Goldziher terkait keotentikan hadits. Artikel ini berjenis studi pustaka (library research). Dengan metode kualitatif dan pendekatan deskriptif-analisis kritis dapat disimpulkan beberapa hal penting: Pertama, pernyataan Goldziher bahwa kodifikasi hadits baru dilakukan setelah beberapa abad wafatnya Nabi itu tidak benar, karena sudah ada beberapa sahabat yang mencatat hadits Nabi meskipun sedikit; Kedua, hadits hanyalah refleksi doktrinal dari perkembangan politik itu tidak tepat, karena tidak ditemukannya data yang otentik dari apa yang dipaparkan Goldziher; Ketiga, tuduhan pelarangan penulisan hadits itu keliru, karena faktanya Nabi hanya melarang jika hadits ditulis dalam satu tempat bersama ayat al-Qur' an untuk menghindari tumpang-tindihnya hadits dengan ayat al-Qur'an; Keempat, tudingan bahwa ahli hadits hanya berfokus pada kritik sanad itu salah, karena sejak dahulu terdapat dua tradisi kritik hadis yakni kritik sanad dan kritik matan yang keduanya tidak dapat dipisahkan dalam menentukan keshahihan hadis.
\end{abstract}

Kata Kunci: Otentitas Hadits, Ignaz Goldziher, Musthafa Azami.

\begin{abstract}
This paper will discuss Ignaz Goldziher's doubts about the authenticity of the hadith. He doubted the authenticity of the hadith with the methodology of historical
\end{abstract}


criticism. This view certainly made Muslim scholars uneasy, because it had become an agreement that hadith was the second source of Islamic law. To answer these doubts, Mustafa Azami criticized his thoughts. Therefore, the author will discuss Musthafa Azami's criticism of Ignaz Goldziher's thoughts regarding the authenticity of hadith. This paper was a library research type. With the qualitative method and descriptivecritical analysis approach, several important conclusions can be drawn: First, Goldziher's statement that the codification of hadith was only carried out after several centuries of the Prophet's death was not true, because there were already several companions who recorded the Prophet's hadith even though it was small; Second, the hadith was only a doctrinal reflection of political development was not correct, because no authentic data had been found from what Goldziher had described; Third, the accusation of prohibiting the writing of hadith was wrong, due to the fact that the Prophet only forbade the hadith to be written in one place with the verses of the Qur'an to avoid overlapping the hadith with the verses of the Qur'an; Fourth, the accusation that hadith experted only focus on sanad criticism was wrong, because long ago there had been two traditions of hadith criticism, namely sanad criticism and matan criticism, both of which cannot be separated in determining the authenticity of hadith.

Keywords: Hadits Authenticity, Ignaz Goldziher, Musthafa Azami.

\section{Pendahuluan}

Usaha orientalis dalam mengkaji tentang dunia Timur, lebih-lebih berkaitan dengan hadits sebenarnya sudah dilakukan sejak lama. Tokoh orientalis yang paling terkenal karya dan pemikirannya seputar studi hadits adalah Ignaz Goldziher. Dia dianggap yang memiliki peran besar dalam pengembangan kajian hadits di kalangan orientalis, meskipun sudah terdapat beberapa tokoh yang terjun di bidang pengkajian hadits seperti Gustav Weil dan Alois Sprenger, yang juga dikenal sebagai penggerak kajian hadits (Setyawan 2018:2). Namun, sangat disayangkan kajian Ignas Goldziher terhadap hadits justru dapat menimbulkan keraguan seorang Muslim dalam memandang keotentikan dan menggunakan sumber hukum kedua dalam Islam ini.

Misalnya, Ignaz Goldziher menggangap bahwa hadits merupakan "produk" atau karangan kaum muslim belakangan, karena kodifikasi hadits baru dilakukan setelah beberapa abad dari masa hidup Rasulullah Saw (Azami 1994:3). Selain itu, metode yang dia gunakan dalam mengakaji hadits adalah metode filosofis serta kritik historis. Pemikiran dan pandangannya tentang hadits dapat dilihat dari beberapa karyanya, khususnya Muslim Studies.

Bagi umat Islam, pendapat Goldziher jelas bertentangan dengan kesepakatan umat Islam bahwa hadits merupakan sumber hokum kedua setelah al-Qur'an dan 
sekaligus sebagai pedoman hidup (Fadhilah, Ristiana, and Aminah 2020:249; Ismail 1995:109) yang berasal dari Rasulullah Saw, sebagai wujud interpretasi nilai-nilai alQur'an itu sendiri (Garwan 2020:140). Oleh karena itu, pendapat dan argumentasinya perlu untuk disanggah dengan kajian otoritatif dan ilmiah.

Di antara ulama yang sangat otoritatif dalam membantah pendapat serta argumentasi Goldziher adalah Muhammad Musthafa Azami. Azami merupakan seorang pakar ilmu hadits, dia gemar menekuni ilmunya dalam bidang hadits, sampai akhirnya dikenal sebagai tokoh Islam yang pertama kali membantah pemikiran Ignaz Goldziher. Menurutnya, tujuan Goldziher tidak lain hanyalah untuk meruntuhkan kepercayaan umat Islam dan membuat keraguan terhadap kredibilitas dan otentitas hadits.

Melalui artikel ini penulis mencoba menghadapkan pemikiran Ignaz Goldziher tentang otentitas hadits dengan kritik Mustafa Azami atas hal tersebut. Hal ini menjadi menarik karena dapat melihat dua sudut pandang berbeda terkait studi hadits yang dilakukan oleh kalangan orientalis (dalam hal ini Goldziher) dan sarjana Muslim (Azami), dimana keduanya memiliki cara tersendiri dalam mengkaji hadits. Penelitian ini berjenis studi pustaka (library research). Oleh karena itu, penulis menggunakan metode kualitatif dengan pendekatan analisis deskriptif-analisis kritis. Data-data terkait pemikiran kedua tokoh tersebut akan penulis eksplorasi dan analisis untuk menjawab beberapa pertanyaan di antaranya, bagaimana asal mula tuduhan Goldziher tentang otentitas hadits? Bagaimana pemikiran Goldziher tentang otentitas hadits? Bagaimana bantahan dan kritik Azami atas pemikiran Goldziher?

\section{Asal Mula Kritik Goldziher terhadap Otentitas Hadits}

Jika melihat sejarah kritik hadits oleh orientalis, Ignaz Goldziher bukanlah orang yang pertama kali menggugat status hadits dalam Islam. Adapun yang pertama kali mempersoalkan status otentitas hadits adalah Alois Sprenger dan dilanjutkan oleh William Munir. Goldziher kemudian menggaungkan tuduhan itu secara kuat (Arif 2005:10). Ada juga yang berpendapat bahwa orientalis yang pertama kali meragukan otentitas hadits adalah Snouck Hurgronje sebagaimana disebutkan oleh A.J. Wensick dalam bukunya "The Importance of Tradition for Studies of Islam"(Darmalaksana 2004:88). 
Meskipun terjadi perbedaan sedemikian rupa, kajian tentang Goldziher sangat dirasa penting karena apa yang sudah ia tulis dalam bukunya, berjudul Mohammedanische Studien (Goldziher 1971). Dalam buku tersebut, Goldziher telah berhasil meragukan otentiitas hadits dengan dilengkapi studi-studi ilmiah yang dia lakukan. Hadits yang dalam Islam merupakan Corpus yang berisi perkataan, perbuatan, atau taqrir yang dinisbatkan kepada Nabi Muhammad Saw, menurut Goldziher tidak lebih dari sekedar catatan-catatan atas kemajuan yang dicapai Islam dalam bidang agama, sejarah dan sosial pada abad pertama dan kedua Hijriyah. Sehingga, hampir tidak mungkin untuk meyakinkan bahwa hadits dapat dinyatakan sebagai asli dari Nabi Muhammad Saw, atau generasi sahabat rasul.

Anggapan Goldziher menganai problem otentisitas hadits ini dikarenakan hadits tidak sama seperti al-Qur'an yang mendapatkan jaminan dari Allah Swt. Sebagaimana dalam surat al-Hijr ayat 9 , berbunyi:

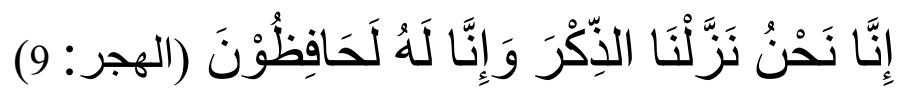

Secara normatif-teologis, hadits tidak mendapatkan jaminan keterpeliharaan dari Allah. Goldziher, sebagai orientalis yang kritis tak lupa menyoroti poin ini dengan menganggap negatif keberadaan hadits. Dan dia mengaggap dirinya sindiri mampu memberikan justifikasi dalam menilai eksistensi dan validitas hadits, meskipun sejatinya dia terkenal memiliki sikap lebik skeptis dibandingkan dengan Sprenger dan Munir (Goldziher 1971:181).

\section{Argumentasi Goldziher tentang Otentitas Hadits}

Seiring perkembangannya, fokus utama kajian orientalis adalah agama Islam dan Bahasa Arab, disamping gagasan, politik, dan teologi yang menyertai kehidupan masa kini. Dalam beberapa kajian orientalis mengenai diskursus-diskursus studi keislaman, dapat dipahami bahwa tujuan utama mereka adalah untuk meluluhlantahkan kepercayaan umat Islam terhadap pedoman mereka yaitu al-Qur'an dan hadits, serta mendiskreditkan Islam itu sendiri.

Sebagaimana disebutkan sebelumnya, bahwa hadits tidak seperti al-Qur'an yang mendapat garansi keterpeliharaannya dari Allah Swt. Dengan berbekal hal ini, para 
orientalis, khususnya Goldziher, menyerang hadits dengan poin ini. Sehingga dia berani mengklaim secara tegas bahwa hadits diragukan otentitasnya.

Ada beberapa pandangan Ignaz Goldziher tentang hal ini, sebagaimana berikut:

Pertama, Ignaz Goldziher memiliki anggapan bahwa hadits merupakan "produk" atau karangan kaum muslim belakangan, karena kodifikasi hadits baru dilakukan setelah beberapa abad dari masa hidup Rasulullah Saw (Azami 1994:3). Kemudian, dia mengatakan bahwa lebih banyak pendapat yang melarang penulisan hadits daripada yang membolehkannya, dan adanya anjuran untuk menghafal hadits dikarenakan masyarakat Arab dahulu lebih kuat pada hafalan. Dia mengemukakan data yang mengindikasikan banyaknya hafalan ditimbang penulisan hadits melalui periwayatan Abu Hurairah, "Tidak ada seorang pun yang hafal lebih banyak hadits selain aku, namun Abdullah ibn 'Ash telah menuliskannya sedangkan aku tidak." Selain itu, pengajaran hadits yang dilakukan oleh Imam Malik ibn Anas kepada muridmuridnya yang dilakukan melalui beberapa teks tertulis, kemudian murid-muridnya menghafal hadits-hadits tersebut lalu Imam Malik mengoreksi hafalan mereka dan menjelaskan maksud hadits tersebut, juga dijadikan penguat justifikasi oleh Goldziher. Dan masih banyak lagi periwayatan-periwayatan yang dijadikan landasan justifikasi oleh Goldziher (Goldziher 1971:183)

Dari pergulatan pemikiran ( $g h a z w$ al-fikr) dan periwayatan yang berkisar pada ranah boleh dan tidaknya penulisan hadits ini, membuatnya berpandangan bahwa pelarangan itu merupakan akibat yang dibiaskan dari prasangka-prasangka buruk yang akan muncul kemudian. Salah satu hadits yang dia kutip adalah hadits yang diriwayatkan oleh Abu Sa'id al-Khudri, lengkapnya:

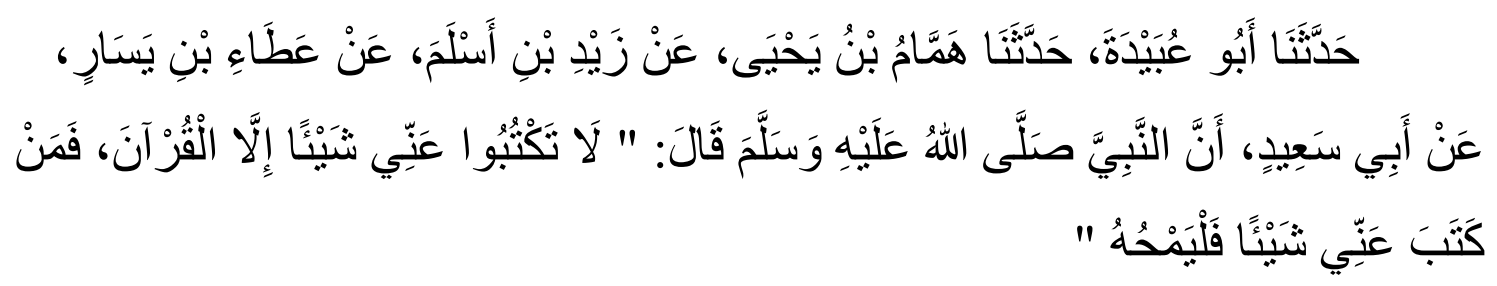

Selain itu, berdasarkan kekhawatiran akan pembolehkan penulisan hadits, Goldziher beranggapan bahwa para sahabat akan lebih cenderung untuk tidak mengoleksi catatan-catatan, sebagaimana yang dilakukan oleh agama-agama terdahulu, 
yang mengabaikan Tuhan tetapi justru mensakralkan tulisan-tulisan mereka (Goldziher 1971:186).

Dalam menguatkan argumentasi tersebut, Goldziher banyak mengutip buktibukti periwayatan yang menjadi legitimasi bagi pembolehan maupun pelarangan penulisan hadits. Terlepas dari mutawatir atau tidaknya periwayatan-periwayatan tersebut. Adapun data-data historis yang membuktikan adanya larangan penulisan hadits yakni pada abad ketiga Hijriyah, tepatnya ketika pujian-pujian yang berlebihan untuk penghafal hadits dan pengutukan penulis hadits yang pernah dilakukan oleh Abu Ali alBashri. Hal itu ia lakukan karena hadits yang dihafalkan lebih terjaga daripada hadits yang ditulis, seperti aman dari bahaya api, air, dan pencuri yang akan mengambil hadits yang tertulis itu. Hal tersebut sebagaimana diungkapkan oleh Abu Sa'ad Abdul Rahman ibn Dost pada abad keempat Hijriyah. Baru kemudian, pada abad keenam Hijriyah, penulisan hadits direkomendasikan oleh sarjanawan terkemuka dari Damaskus, yaitu Abu al-Qasim ibn Asakir (Goldziher 1971:186).

Dari semua ungkapan Goldziher tersebut, sangat jelas adanya keraguan darinya untuk meyakini otentitas hadits yang sudah ada sejak masa Nabi Saw, sahabat, maupun masa tabi'in. Dengan kata lain, hadits hanyalah karya-karya ulama terdahulu (masa setelah Nabi Saw wafat) yang disebarkan untuk menyikapi kasus-kasus dan fenomenafenomena sosial yang terjadi di tengah masyarakat pada waktu itu.

Kedua, Ignaz Goldziher beranggapan bahwa hadits-hadits yang sudah terhimpun baik yang disandarkan kepada Nabi Saw, maupun para sahabat itu bukan sesuatu yang otentik, melainkan hanya sebatas refleksi doktrinal yang muncul sejak perkembangan politik pada abad pertama Hijriyah setelah wafatnya Nabi Saw. Bagi Goldziher, hampir tidak mungkin untuk menyaring sedemikian banyaknya materi hadits, hingga dia mengklaim bahwa sedikit sekali hadits yang masih otentik (Goldziher 1971:183).

Dia juga menuduh bahwa perawi-perawi hadits meriwayatkan haditsnya dengan mengatasnamakan Nabi Muhammad Saw, padahal beliau sendiri tidak pernah mengatakan seperti itu. Selain itu, dia mengklaim bahwa hadits itu palsu dikarenakan periwayatannya sarat dengan kepentingan politis dan ideologis kaum muslimin yang sudah terpecah belah. Goldziher juga menambahi bahwa hadits Nabi hanyalah refleksi atas kecenderungan-kencenderungan awal masa Islam berkembang, dan bukanlah 
representasi kelahiran Islam. Jadi, dapat dikatakan bahwa hadits adalah tradisi masyarakat Arab. Dia menilai bahwa hadits bukanlah sumber yang bernilai dan penting bagi dogma maupun konflik. Dan perlu diketahui bahwa tokoh orientalis seperti Leone Caetani dan Henri Lammens mengadopsi pemikiran Goldziher ini dan meragukan hampir seluruh riwayat seputar kehidupan Nabi Saw (Sumbullah 2010:170).

Ketiga, Ignaz Goldziher juga mengklaim bahwa sebenarnya tradisi penulisan hadits merupakan pengadopsian dari beberapa ajaran-ajaran agama Yahudi yang melarang untuk menulis hal-hal yang berkaitan dengan aturan-aturan mereka. Namun, sangat disayangkan karena sebagian sarjana muslim mendukung pendapat tersebut, meskipun jelas bertentangan dengan fakta-fakta yang ada. Menurut Goldziher, dukungan dari sarjana muslim tersebut tidak bisa dilepaskan dari kepentingan ideologis, karena mereka khususnya dan umat muslim umumnya, tidak memiliki bukti yang menunjukkan bahwa Nabi Muhammad Saw mencatat riwayat-riwayat selain al-Qur'an serta tidak ada bukti bahwa penulisan hadits itu sudah terjadi sejak awal Islam (Goldziher 1971:182).

Keempat, Ignaz Goldziher mengklaim bahwa matan hadits yang telah diriwayatkan oleh perawi-perawi hadits itu tidak akurat, dikarenakan penekanan matan hadits ada pada maknanya, yang menyebabkan beberapa ahli bahasa enggan menerima periwayatan hadits yang menganggap bahwa susunan bahasa memiliki ketergantungan pada pendapat periwayatnya (Goldziher 1971:187).

Dia juga berpendapat bahwa hadits yang telah diteliti oleh ulama ahli hadits (muhadditsin) terdahulu tidak dapat dipertanggung-jawabkan secara ilmiah karena kelemahan metodenya. Menurutnya, hal itu disebabkan para ulama hadits tersebut kurang mengedepankan metode kritik matan, tetapi lebih mendahulukan metode kritik sanad. Sehingga, dia menganggap bahwa banyak sekali ditemukan hadits yang pada awalnya dianggap shahih ternyata palsu. Baginya kritik matan hadits merupakan hal yang perlu dilakukan. Oleh karena itu, kritik matan hadits sejatinya mencakup banyak aspek di antaranya aspek politik, aspek sosio-kultural, aspek sains, dan lain sebagainya (Azami 1994:15).

Adapun yang menjadi sebab Goldziher meragukan keshahihan hadits Nabi Saw, dikarenakan empat alasan, sebagai berikut (Ya'qub 1995:13): 
1. Tidak disebutkannya sumber tertulis pada koleksi hadits belakangan dan sering memakai istilah-istilah isnad yang menginterpretasikan periwayatan lisan daripada periwayatan tertulis.

2. Beberapa hadits saling kontradiktif satu sama lainnya.

3. Hadits yang berkembang secara massal pada koleksi hadits belakangan tidak termuat dalam koleksi hadits yang lebih awal.

4. Menganggap bahwa lebih banyak sahabat kecil yang meriwayatkan hadits daripada sahabat besar, karena menurutnya mereka lebih banyak mengetahui tentang Nabi Saw.

Semua alasan tersebut oleh Goldziher dijadikan bukti bahwa telah terjadi pemalsuan hadits yang dilakukan dalam skala besar. Ia bersikukuh bahwa tidak dapat hanya menyandarkan pada kritik sanad dalam menentukan keshahihan hadits. Seharusnya, harus lebih menekankan pada korelasi antara teks hadits dengan konteks sosial-politik yang ada saat hadits itu muncul. Dengan kata lain, hadits menurut Goldziher adalah alat yang dipakai untuk menjaga hegemoni kepentingan tertentu, politik maupun keagamaan, dan bukan sebuah alat yang dipakai untuk memahami perilaku Nabi Saw (Badawi 2003:131).

Dalam hal ini, salah satu hadits yang dikritik oleh Goldziher adalah hadits yang terdapat dalam Kitab Shohih Bukhari, karena menurutnya Imam Bukhari hanya fokus pada kritik sanad dan tidak melakukan kritik matan, sehingga setelah adanya kritik matan oleh Goldziher, hadits tersebut dinyatakan palsu. Sebagai langkah untuk menguatkan argumennya tersebut, Goldziher memberi contoh hadits Nabi Saw yang diriwayatkan dalam Kitab Shohih Bukhari, yang berbunyi:

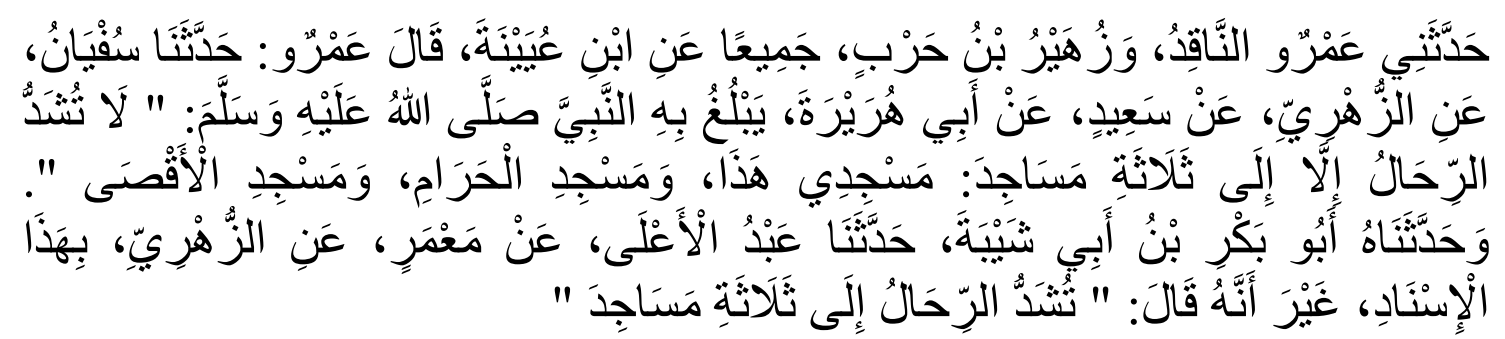

Berkenaan hadits di atas, menurut Goldziher, Abd Malik ibn Marwan (khalifah dari dinasti Umayyah di Damaskus) khawatir orang-orang Syam yang pergi haji ke Mekkah akan melakukan baiat setia kepada rivalnya yakni 'Abdullah ibn al-Zubair 
(yang memproklamirkan dirinya sebagai khalifah di Mekkah). Karena itu, ia berusaha agar orang-orang dapat melakukan ibadah haji di Qubbah al-Shakhrah di al-Quds (Jerusalem) sebagai ganti pergi haji ke Mekkah. Selain itu, dia juga memberikan maklumat bahwa nilai/pahala tawaf di sekitar al-Shakhra sama seperti tawaf di sekitar Ka'bah (Azami 1994:609). Goldziher beranggapan bahwa demi mencapai tujuan politisnya itu, 'Abd al-Malik ibn Marwan menyuruh seorang ahli hadits, al-Zuhri untuk membuat sebuah hadits yang bersambung sampai Nabi Muhammad Saw, dan menyebarkannya ke masyarakat yang bertujuannya agar masyarakat paham bahwa terdapat tiga masjid yang sah untuk dipakai beribadah haji yaitu masjid di Mekkah, Masjid di Madinah, dan masjid di al-Quds (Jerusalem) (Goldziher 1971:35).

Di samping dia menuduh seperti di atas, dia juga menuduh bahwa 'Abd al-Malik meniadakan ibadah haji, atau setidaknya berusaha meniadakan ibadah haji. Untuk menguatkan tuduhannya tersebut, dia mengkutip perkataan al-Ya'qubi dalam kitabnya al-Tarikh, sebagai berikut (Goldziher 1971:35): "Abd al-Malik melarang orang-orang Syam untuk melakukan ibadah haji. Hal itu karena Ibn al-Zubair akan menyuruh mereka (orang-orang Syam yakni Syiria dan sekitarnya) melakukan baiat kepadanya apabila mereka datang ke Mekkah. Maka, gemparlah orang-orang Syam. Mereka memprotes hal itu, kemudian mempertanyakannya kepada 'Abd al-Malik, "Apakah anda melarang kami untuk pergi ibadah haji ke Makkah, sedangkan ibadah haji hukumnya wajib bagi kami?" Jawab "Abd al-Malik, "Ini Ibn Syihab al-Zuhri meriwayatkan hadits untuk kalian bahwa Rasulullah Saw, bersabda: "Tidak dikencangkan tali kendaraan, maksudnya: Janganlah kalian pergi, kecuali tiga masjid. Masjid al-Haram, Masjid Nabawi, dan Masjid al-Aqsha.” (Goldziher 1971:35)

Sehingga, dapat ditarik kesimpulan bahwa hadits dalam Kitab Shahih Bukhari itu tidak shahih dikarenakan bukan sabda Rasulullah Saw, karena dibuat oleh al-Zuhri sebagai pewujud ambisi politik Khalifah 'Abd al-Malik, meskipun hadits itu terdapat pada Shahih Bukhari yang diakui otentitasnya oleh seluruh umat muslim, bahkan dianggap sebagai kitab paling shahih setelah al-Qur'an.

\section{Kritik Musthafa Azami terhadap Pemikiran Ignaz Goldziher}

Adapun sarjana muslim yang dipandang sebagai seorang yang pertama kali melakukan penolakan dan bantahan terhadap argumentasi Ignaz Goldziher yang 
meragukan otentitas hadits adalah Muhammad Musthafa Azami. Azami mengatakan bahwa sampai sekarang otentitas hadits masih dapat dibuktikan baik secara ilmiah maupun historis. Dia menunjukkan beberapa fakta bahwa semua masalah mengenai hadits Nabi bertumpu pada masalah sentral tentang status Sunnah yang merupakan ajaran kedua setelah al-Qur'an. Dimana Sunnah merupakan cerminan kehidupan Nabi Saw, baik ucapan, perbuatan, maupun sikap diam Nabi Saw, yang tentunya menjadi suri tauladan bagi umat Islam di seluruh dunia tanpa terikat oleh ruang dan waktu. Karena alasan ini pula, maka sejak masa para sahabat sudah dilakukan penyebaran ilmu-ilmu tentang Sunnah. Bahkan hal itu juga diperintahkan oleh Nabi Saw (Azami 1992:6). Untuk menanggapi beberapa pemikiran Ignaz Goldziher di atas, akan diulas catatan kritis yang dilontarkan dan analisis melalui beberapa argumen.

Pertama, Goldziher mengklaim bahwasanya hadits hanyalah produk dari kaum muslim belakangan ini, dikarenakan adanya kodifikasi hadits baru dilakukan setelah beberapa abad semenjak wafatnya Nabi Saw. Hal ini mendapat bantahan dari Azami, bahwa masyarakat Arab sudah terkenal maju dan berkebudayaan jauh sebelum kedatangan Islam. Sehingga, tidak dapat dikatakan jika tidak terdapat sama sekali tradisi tulis-menulis di kalangan masyarakat Arab karena banyaknya bukti-bukti sejarah mengenai hal itu, meskipun para sahabat dikenal lebih mengandalkan hafalan daripada tulisan. Sehingga, dapat dikatakan bahwa sejak masa pra-Islam masyarakat Arab sudah masyhur dengan tradisi penulisannya, dibuktikan dengan banyaknya syair yang telah digubah oleh para penyair Arab. Meskipun demikian, mereka lebih mengutamakan hafalan daripada tulisan yang mereka anggap tabu (Al-Khatib 1988:140). Ketabuan ini berimbas pada penulisan hadits sampai periode tabi'in dan telah menjadi fenomena umum.

Bukti lain yang menguatkan adanya tradisi tulis menulis di kalangan masyarakat Arab (umumnya) dan sahabat (khususnya) yaitu wahyu yang turun kepada Nabi Muhammad Saw, dicatat oleh 40 sahabat yang terpilih, yang selalu siaga untuk menulis wahyu-wahyu yang turun setiap saat (Azami 1992:10). Jika dikelompokkan secara umum, para pencatat wahyu itu terbagi menjadi tiga kelompok, yaitu kelompok Quraisy Muhajirin, Bani Tsaqif, dan Anshar (Al-Qatthan 1978:66). 
Dalam hal ini Azami sependapat dengan al-Baqillani yang membagi sahabatsahabat yang mencatat wahyu itu menjadi empat kelompok, yaitu: Pertama, para sahabat yang menjadi sekretaris Nabi Saw; Kedua, beberapa sahabat yang cakap dalam membaca dan menulis sekaligus; Ketiga, sahabat Nabi Saw, yang masih tidak ada keterangan kecakapannya dalam membaca dan menulis; Empat, orang-orang yang tidak terdapat pada kitab yang membahas biografi sahabat (Azami 2008:xx-xxv). Azami menyatakan bahwa masing-masing sekretaris Nabi berdasarkan intensitas menulis untuk Nabi tentu terdapat perbedaan. Karena itu, Azami mengelompokkan kepada tiga kelompok: Pertama, kelompok sahabat yang sudah masyhur sebagai juru tulisnya Nabi Saw, di antaranya Ali ibn Abi Thalib, Utsman ibn Affan, Zaid ibn Tsabit, dan lainnya. Kedua, mereka yang dikenal sebagai sekretaris tetapi frekuensi menulisnya lebih rendah dari pertama. Di antaranya adalah Abu Bakar al-Shiddiq, Umar ibn al-Khatthab, Abu Ayyub al-Anshari, dan lainnya. Ketiga, kelompok sahabat yang tercantum dalam kitab al-Wasa'iq al-Siyasiyyah dan kitab lain, tetapi Azami tidak menemukan ketagasan bahwa mereka sekretaris Nabi (Azami 2008:xxx). Ada juga Sa'ad 'Abdullah ibn 'Auf yang memiliki kumpulan hadits yang ditulis tangan sendiri (Shalih 2007:24).

Di antara proses penyebaran hadits yang dilakukan oleh para sahabat melalui tulisan di antaranya berupa surat-surat Nabi Muhammad Saw, yang dikirim kepada para raja, penguasa, gubernur muslim dan kepala suku yang ada. Selain itu, juga terdapat beberapa catatan khusus bagi beberapa sabahat, seperti Ali bin Abi Thalib, 'Abdullah ibn 'Amr ibn al-'Ash dan Abu Syah (Azami 1994:10). Dan Abu Hurairah pun yang terkenal di kalangan umat muslim sebagai salah satu sahabat yang banyak memiliki riwayat hadits juga memiliki buku yang di dalamnya memuat catatan hadits-hadits dan diberikan kepada murid-muridnya. Anas ibn Malik memberikan catatan-catatan hadits kepada 16 orang, Aisyah setidaknya memberikan catatan hadits kepada tiga orang, di antaranya adalah keponakannya sendiri, Urwah (seorang tabi'in), dan banyak lagi sahabat yang mencatat hadits-hadits kemudian diberikan kepada murid-muridnya (Azami 1994:26-27).

Pada perkembangan selanjutnya, sekitar abad ketiga Hijriyah mulai bermunculan beberapa shahifah yang memuat hadits Nabi Saw. Berdasarkan pernyataan Abu Hasan al-Nadwi bahwa shahifah-shahifah ini menjadi sumber-sumber utama kitab hadits di abad ketiga Hijriyah dalam bentuk kitab Jawami', Masanid, dan Sunan. Akan 
tetapi, pendapat yang sudah umum bahwa hadits mulai ditulis dan tercatat di abad ketiga Hijriyah, sementara tadwin hadits (kodifikasi hadits) baru dimulai di abad kedua Hijriyah. Ada dua faktor yang menyebabkan munculnya pendapat tersebut yaitu: Pertama, para ahli sejarah tidak pernah menyebut shahifah-shahifah dan kumpulan catatan hadits yang sudah ada sejak abad ketiga Hijriyah, pendapat mereka hanya didasarkan hal yang terkait tadwin. Kedua, ahli sejarah tidak pernah menyebutkan jika kitab-kitab hadits yang banyak dan tebal-tebal itu berasal dari himpunan lembaranlembaran kecil dan catatan-catatan yang berserakan sejak abad pertama Hijriyah (Azami 1994:56).

Dari sini dapat ditarik kesimpulan bahwa, Azami bersikukuh dengan pandangannya bahwa dalam penyebaran hadits tidak hanya menggunakan metode lisan akan tetapi juga tulisan. Ini merupakan usahanya untuk membantah tuduhan kalangan orientalis lebih-lebih Ignaz Goldziher tentang diragukannya otentitas hadits Nabi. Semua usaha yang dilakukan oleh para sahabat tersebut, mulai dari menghafal, menulis, mengumpulkan lembaran-lembaran, hingga menyusunnya menjadi berwujud buku atau kitab, adalah untuk menjaga dan melestarikan hadits-hadits Nabi Muhammad Saw. Sebab itu, diperlukan tulisan sebagai tali pengikat untuk menolong dan menjaga kualitas hafalan. Dengan demikian, klaim Goldziher yang mengatakan bahwa masyarakat Arab dahulu lebih mengutamakan hafalan serta menjaga tradisi dan budayanya tanpa disertai tulisan, maka itu sangat sulit terjadi (Azami 1994:72). Rangkaian masa penulisan hadits tersebut berdasarkan kepercayaan bahwa hadits tidak hanya diriwayatkan melalui lisan semata, akan tetapi juga tertulis oleh perawi terpercaya dengan alat yang ada.

Kedua, Goldziher meragukan otentitas hadits yang disandarkan kepada Nabi Muhammad Saw, dan para sahabat yang terhimpun dalam kumpulan hadits-hadits klasik. Baginya hadits-hadits tersebut hanya merupakan refleksi dokrinal dari perkembangan politik dalam dua abad pertama sejak wafatnya Nabi Saw. Hal itu dibantah oleh Musthafa Azami, bahwa sejak awal munculnya Islam, Nabi Muhammad Saw, memegang hak prerogatif keagamaan setelah Allah Swt, terbukti dengan dijadikannya beliau sebagai tempat rujukan dari masalah-masalah yang muncul di kalangan para sahabat dengan berbagai sabda dan perbuatannya, yaitu hadits. Oleh karena itu, meskipun penulisan dan pengkodifikasian hadits dilakukan jauh dari masa hidupnya Nabi Muhammad Saw, tidak dapat meragukan validitas dan otentitas hadits. 
Lebih-lebih banyak kalangan ulama ahli hadits pada masa belakangan yang melakukan upaya serius dalam memverifikasi hadits, dibuktikan dengan karya-karyanya yang berisi kritik, baik dari segi sanad maupun matan sebagai upaya membentengi hadits-hadits palsu.

Azami mengkritik Goldziher mengenai metode penelitian yang dia gunakan dalam meragukan otentisitas hadits. Dia mengatakan bahwa Goldziher lemah dalam kebenaran materi sejarahnya. Selain Azami, tuduhan seperti ini juga dilakukan oleh beberapa pakar hadits, di antaranya seperti Prof. Dr. Musthafa al-Siba'iy (al-Sunnah wa Makanatuha fi al-Tasyri'i al-Islam) dan Prof. Dr. 'Ajjaj al-Khatib (al-Sunnah Qabla Tadwin). Menurut mereka, keraguan Goldziher terhadap keotentikan hadits dikarenakan ketidak-tahuan dan kurang percayanya pada bukti-bukti sejarah (Zainuddin 2016:282).

Metodologi para orientalis dinilai Azami memiliki kerancuan dan ketidakkonsistenan dalam meneliti perkembangan hadits yang berkenaan dengan hukum. Sebab mereka malah memasukkan hadits-hadits ritual dan bukannya yang berkaitan dengan hukum. Misalnya adalah dari 47 hadits yang diklaimnya benar berasal dari Nabi sebagiannya bukan berasal dari Nabi bahkan tidak ada kaitannya dengan hukum melainkan hanya seperempat yang sesuai dengan topik yang didiskusikan (Zainuddin 2016:288).

Ada juga argumen yang dapat meruntuhkan klaim Goldziher yakni teks hadits itu sendiri. Sebagaimana hadits yang dia kutip dari Kitab Shahih Bukhari, hadits itu sebenarnya sama sekali tidak memberikan isyarat apapun yang bisa menunjukkan bahwa ibadah haji dapat dilakukan di al-Quds (Jerussalem), melainkan hanya isyarat pemberian keistimewaan kepada Masjid al-Aqsha, dan ini merupakan hal yang wajar dikarenakan Masjid al-Aqsha pernah menjadi kiblat kaum muslimin. Di samping itu, tawaran dari Goldziher agar kritik hadits tidak semata-mata didekati lewat perspektif sanad akan tetapi juga lewat kritik matan, perlu dicermati. Sebenarnya semenjak awal para sahabat dan generasi sesudahnya sudah mempratekkan metode kritik matan. Sebagaimana penjelasan argumentatif telah disampaikan oleh Subkhi al-Shalih bahwa ulama dalam mengkaji hadits juga bertumpu matan (Zainuddin 2016:283).

Sudah menjadi ketentuan bahwa untuk menentukan suatu hadits itu shahih atau palsu, muhadditsin sejak dahulu sudah menetapkan dua metode kritik hadits yaitu kritik 
sanad dan kritik matan. Fokus kajian dari kritik sanad adalah kesinambungan rantai periwayatan dan kredibilitas perawi hadits, sedangkan kritik matan terfokus pada redaksi hadits (Ismail 1992:4-5). Kritik hadits sendiri dalam bahasa Arab disebut "naqd", secara etimologi artinya pemisah (Al-Ifriqiy 1993:425), dan secara terminologi bermakna sebagai usaha para ulama untuk memvalidasi suatu hadits itu shahih atau saqim (cacat) (Al-Raziy 1952:3). Definisi naqd tersebut menunjukkan bahwa kritik hadits yang dilakukan oleh ulama sejak dahulu merupakan sebuah usaha dalam menguji keshahihan hadits dari segi historisitas (Idri 2015:141). Kaidah-kaidah yang berkaitan dengan kedua kritik ini dimasukkan dalam satu disiplin ilmu tersendiri yang dinamakan 'ulumul hadits (Idris 2016:134).

Ketiga, tuduhan Goldziher mengenai alasan pelarangan penulisan hadits yang menurutnya dikarenakan pengadopsian aturan-aturan agama sebelum Islam. Klaim ini tidak representatif bahkan terkesan mengada-ada. Adapun alasan pelarangan penulisan ini karena timbulnya sebuah kekhawatiran apabila hadits bercampur dengan al-Qur'an. Sebab berdasarkan historisnya, ketika para sahabat mendengar $t a$ 'wil ayat lalu mereka menuliskannya dalam shahifah yang sama dengan al-Qur'an. Hal yang perlu diketahui lagi, bahwa Goldziher mempunyai semangat yang luar biasa dalam mencari titik kelemahan Islam, terutama berkaitan dengan hadits. Rupanya dia menjadikan hadits Abu Sa'id al-Khudri sebagai pijakan pelarangan penulisan hadits dan hadits Abu Hurairah sebagai dasar pijakan penulisan hadits. Sikap Goldziher dalam menyikapi kedua hadits ini sebagai sesuatu yang saling bertentangan adalah sebuah kekeliruan. Hakikatnya, kedua hadits tersebut bisa dikompromikan dengan cara menggabungkan atau men-tarjih keduanya, seperti yang telah diterapkan (Qardhawi 1999:117).

Keempat, Ignaz Goldziher menilai bahwa tidak adanya keakuratan pada redaksi/matan hadits yang diriwayatkan perawi-perawi hadits. Hal itu menurutnya disebabkan oleh kecenderungan perawi lebih terfokus pada aspek makna hadits yang menyebabkan para ahli bahasa tidak mau menerima periwayatan hadits disebabkan susunan bahasanya bergantung pada pendapat perawinya. Pernyataan Goldziher tersebut dibantah oleh Musthafa Azami. Dia mengatakan bahwa tuduhan Goldziher tersebut tidaklah beralasan, karena pada dasarnya tradisi periwayatan hadits terbagi menjadi dua, yaitu periwayatan bi al-lafdzi dan periwayatan bi al-ma'na. Jenis periwayatan kedua ini yang menjadi sorotan Goldziher dengan argumennya yang menyatakan bahwa perawi 
hadits yang menerapkan tradisi periwayatan bi al-ma'na dicurigai telah meriwayatkan lafadz-lafadz yang dengan sengaja disembunyikan, sehingga redaksinya menjadi tidak akurat. Padahal bila ditelusuri lagi, adanya tradisi periwayatan bi al-ma'na karena sahabat Nabi Muhammad Saw, tidak begitu hafal lapal aslinya. Sehingga yang terpenting adalah mengetahui kandungan hadits. Di samping itu, tradisi ini tidak dilarang oleh Nabi Muhammad Saw, mengingat matan hadits bukanlah al-Qur'an yang tidak boleh dirubah susunan bahasa dan maknanya, baik itu dengan mengganti lafadzlafadz yang muradif (sinonim) yang tidak terlalu perlu mengetahui isinya, berbeda dengan al-Qur'an sebab merupakan mukjizat dari Allah Swt, yang tidak boleh dan tidak mungkin bisa berubah (Rahman 2007:21).

Menurut Azami, untuk memperoleh keotentikan hadits, peneliti hadits perlu melakukan kritik hadits baik itu menyangkut sanad maupun matan. Kritik sanad hadits dilakukan melalui dua langkah, yaitu: Pertama, menguji ke-'adil-an dan ke-dhabt-an para perawi hadits (ke-tsiqah-an periwayat). Dimana hal ini membahas tentang jarh wa al-ta'dil. Kedua, pengujian mengenai kesinambungan sanad-sanad. Oleh karenanya, perlu sebuah perangkat teoritis tantang tahammul wa ada' al-hadits. Ketiga, penyimpulan mengenai studi sanad yang telah dilakukan, yakni hanya menyangkut apakah sanadnya shahih atau dha'if. Sedangkan penelitian matan meliputi: Pertama, matan hadits tidak shad, yakni adanya kontradiksi periwayat satu dengan periwayat yang lain memiliki perbedaan tingkat ke-tsiqah-an. Hal ini dilakukan dengan cara mengkorfirmasi matan dengan ayat-ayat al-Qur'an dan beberapa hadits lain yang berkaitan. Kedua, matan harus ghayr al-mu'allal, yaitu bahwa matan hadits tidak boleh memiliki cacat. Dilakukan dengan mengkorfirmasi dengan dalil aqli, yang meliputi kontradiksi dengan akal, indera, sejarah, dan tidak menyerupai perkataan kenabian. Ketiga, pengambilan kesimpulan mengenai ke-shahih-an atau ke-dha'if-an matan (Ulum and Ihsan 2020:177-79).

Salah satu contoh kritik Azami terhadap argumentasi Goldziher tentang kekeliruan metode kritik hadits yang diterapkan Goldziher adalah bantahannya terhadap kritik Goldziher perihal hadits riwayat al-Zuhri. Sebelumnya, Goldziher memberikan sebuah contoh di zaman ketika Khalifah 'Abd al-Malik ibn Marwan yang karena khawatir orang-orang Syam yang menjalankan haji ke Mekkah akan melakukan baiat setia kepada 'Abdullah ibn Zubair. Ia kemudian menyerukan agar kaum muslimin 
beribadah haji di Qubbah al-Shakhra di Jerussalem. Selanjutnya, ia mengutus Ibnu Syihab al-Zuhri membuat suatu hadits yang sanadnya bersambung sampai Nabi Saw, dan mendengarkannya ke masyarakat untuk melancarkan rencana politisnya. Peristiwa inilah yang menurut Goldziher melatarbelakangi munculnya hadits yang berbunyi, " $L a$ tasyuddu al-rihala illa tsalasati masajida, masjid hadza wa al-masjid al-haram wa almasjid al-Aqsha" (Goldziher 1971:44).

Menurut Goldziher, sekalipun hadits ini tertulis dalam Kitab Shahih Bukhari bukan berarti otentik sabda Nabi Saw, melainkan hadits palsu karena dikarang al-Zuhri. Al-Zuhri, menurut Goldziher mendapat paksaan dari Khalifah 'Abd al-Malik ibn Marwan untuk membuat hadits itu karena kekhawatirannya apabila warga Syam yang pergi haji ke Mekkah akan disuruh untuk berbaiat dengannya (Goldziher 1971:45).

Muhadditsin menegaskan tidak terdapat bukti historis yang kuat untuk mendukung teori Goldziher ini, bahkan sebaliknya. Para ahli tarikh berbeda pendapat tentang kelahiran al-Zuhri, antara 50-58 H. Al-Zuhri juga belum pernah bertemu dengan 'Abd al-Malik ibn Marwan sebelum tahun $81 \mathrm{H}$. Pada tahun $68 \mathrm{H}$ orang-orang dari Dinasti Umayyah berada di Makkah pada musim haji. Apabila demikian adanya, alZuhri pada waktu itu masih berumur 10 sampai 18 tahun. Dan sangat tidak logis seorang anak yang baru berumur belasan tahun sudah populer sebagai intelektual dan memiliki reputasi ilmiah di luar daerahnya sendiri, dimana dia mampu mengubah pelaksanaan ibadah Haji dari Mekkah ke Jerussalem. Lagi pula di Syam pada saat itu masih banyak para sahabat dan tabi'in yang tidak mungkin diam saja melihat kejadian itu (Azami 1994:280).

Di sisi lain, pada tahun $67 \mathrm{H}$, Palestina berada di luar kekuasaan 'Abd al-Malik ibn Marwan, sedangkan orang-orang Bani Umayyah pada tahun $68 \mathrm{H}$ berada di Makkah dalam musim haji. Dari data-data tersebut menurut Azami, dapat disimpulkan bahwa 'Abd al-Malik ibn Marwan tidak mungkin mempunyai pikiran untuk membangun Qubbah al-Shakhra', sebagai pengganti Ka'bah, kecuali sesudah tahun 68 H. Sumbersumber sejarah sendiri justru menunjukkan bahwa pembangunan Qubbah al-Syakhra' baru dimulai pada tahun $69 \mathrm{H}$ (Azami 1994:610).

Cermat Azami telah terjadi perubahan teks yang dilakukan oleh Goldziher yang sebenarnya berbunyi al-hadits, akan tetapi ditulis dengan lafadz hadits saja. Begitupun 
tesis Goldziher yang menyatakan bahwa al-Zuhri dipaksa Khalifah 'Abd al-Malik ibn Marwan (yang bermusuhan dengan Ibn al-Zubair) untuk membuat hadits adalah palsu atau bohong. Berdasarkan data yang ada, al-Zuhri tidak pernah bertemu dengan 'Abd alMalik semasa hidupnya, kecuali sesudah tujuh tahun dari wafatnya Ibn al-Zubair. Pada saat itu, al-Zuhri berumur 10-18 tahun sehingga tidak logis pemuda seperti itu memiliki reputasi dan otoritas yang kuat untuk mempengaruhi masyarakat di sekitarnya (Azami 1994:610).

Kata-kata "al-hadits" dalam kutipan Goldziher tanpa memakai "al" yang menunjukkan lafadz yang sudah terdefinisikan (ma'rifah). Sementara teks aslinya seperti yang tercantum dalam kitab karya Ibn Sa'ad dan Ibn "Asakir adalah "al-hadits" yang berarti hadits-hadits yang telah dimaklumi secara definitif yakni hadits-hadits yang berasal dari Nabi Saw. Jadi, maksud perkataan al-Zuhri sesungguhnya adalah ada paksaan dari para pejabat untuk menuliskan hadits-hadits Nabi Saw, yang pada saat itu sudah ada (Zainuddin 2016:281).

Sementara dari segi teks haditsnya tidak mengindikasikan kalau ibadah haji boleh dilakukan di Jerussalem. Namun hanya berupa isyarat pengistimewaan Masjid alAqsha sebagai tempat yang pernah menjadi kiblat umat Islam. Dan di lain sisi, hadits tersebut diriwayatkan oleh 18 orang selain al-Zuhri (Azami 1994:613).

Bantahan Azami di atas secara tegas menunjukkan kekeliruan klaim Goldziher bahwa para ulama hanya mementingkan kritik sanad. Ibarat dua mata uang, kritik matan tidak dapat dilepaskan dari kritik sanad sebagai upaya validasi otentitas hadits (Suryadi 2015:182). Kritik matan ini perlu dilakukan karena banyaknya penyebaran hadits palsu di masa periwayatan hadits, juga karena ada berbagai kekeliruan (al-wahm) dalam periwayatan hadits (Tangngareng 2016:106).

\section{Kesimpulan}

Dari pelbagai pejelasan di atas dapat disimpulkan bahwa asal mula tuduhan Ignas Goldziher terkait ketidakotentikan hadits adalah karena dia melihat bahwa hadits tidak ada jaminan sebagaimana al-Qur'an yang telah terjamin. Bermula dari sini, dia menganggap bahwa hadits tidak otentik dengan berbagai alasan: Pertama, Goldziher menganggap bahwa kodifikasi hadits baru dilakukan setelah beberapa abad setelah wafatnya Nabi; Kedua, hadits hanyalah refleksi doktrinal dari perkembangan politik; 
Ketiga, tuduhan pelarangan penulisan hadits; Keempat, tudingan bahwa ahli hadits hanya berfokus pada kritik sanad. Untuk mengkritik dan membantah tuduhan menyesatkan ini, Muhammad Musthafa Azami menjelaskan bahwa hadits Nabi bertumpu pada masalah sentral tentang status Sunnah yang merupakan ajaran kedua setelah al-Qur'an. Dimana Sunnah merupakan cerminan kehidupan Nabi Saw, baik ucapan, perbuatan, maupun sikap diam Nabi Saw, yang tentunya menjadi suri tauladan bagi umat Islam. Selain itu, untuk membantah keempat tuduhan Ignas Goldziher, Azami menjawab: Pertama: pernyataan Goldziher bahwa kodifikasi hadits baru dilakukan setelah beberapa abad wafatnya Nabi itu tidak benar, karena sudah ada beberapa sahabat yang mencatat hadits Nabi meskipun sedikit; Kedua, hadits hanyalah refleksi doktrinal dari perkembangan politik itu tidak tepat, karena tidak ditemukannya data yang otentik dari apa yang dipaparkan Goldziher; Ketiga, tuduhan pelarangan penulisan hadits itu keliru, karena faktanya Nabi hanya melarang jika hadits ditulis dalam satu tempat bersama ayat al-Qur'an untuk menghindari tumpang-tindihnya hadits dengan ayat alQur'an; Keempat, tudingan bahwa ahli hadits hanya berfokus pada kritik sanad itu salah, karena sejak dahulu terdapat dua tradisi kritik hadits, yakni kritik sanad dan kritik matan yang keduanya tidak dapat dipisahkan dalam menentukan keshahihan hadits. Dari sini dapat dikatakan kritik Muhammad Musthafa Azami merupakan kritik tajam untuk menjawah tuduhan-tuduhan tersebut.

\section{DAFTAR PUSTAKA}

Al-Ifriqiy, Muhammad ibn Mukrim ibn al-Manzhur. 1993. Lisan Al-'Arab. Beirut: Dar al-Shadir.

Al-Khatib, Muhammad 'Ajaj. 1988. Al-Sunnah Qabla Al-Tadwin. Beirut: Dar al Fikr.

Al-Qatthan, Manna' Khalil. 1978. Mabahits Fi 'Ulum Al-Qur'An. Beirut: Dar al Fikr.

Al-Raziy, 'Abd al-Rahman ibn Muhammad Abu Hatim. 1952. Al-Jarh Wa Al-Ta'dil. Beirut: Ihya' al-Turats al-'Arabiy.

Arif, Syamsuddin. 2005. "Gugatan Orientalis Terhadap Hadits Dan Gaungnya Di Dunia Islam.” Jurnal Al-Insan 1(2).

Azami, Muhammad Mushtafa. 1992. Studies in Hadits Methodology and Literature: Metodologi Kritik Hadits, Terj. A. Yani. Bandung: Pustaka Hidayah.

Azami, Muhammad Mushtafa. 2008. 65 Sekretaris Nabi Shallallahu 'Alaihi Wa Sallam, Terj. Mahfuzh Hidayat Lukman. Jakarta: Gema Insani Press.

Azami, Muhammad Musthafa. 1994. Hadits Nabawi Dan Sejarah Kodifikasinya, Terj. Ali Mushtafa Ya'qub. Jakarta: Pustaka Firdaus. 
Badawi, Abdurrahman. 2003. Mawsu'ah Al-Mustasyrikin, Terj. Ensiklopedi Orientalis,. Yogyakarta: LKIS.

Darmalaksana, Wahyudin. 2004. Hadits Di Mata Orientalis: Telaah Atas Pandangan Ignaz Goldziher Dan Josep Schacht. (Bandung: Benang Merah Press.

Fadhilah, Sinta Rahmatil, Umu Nisa Ristiana, and Siti Aminah. 2020. "Interpretasi Hadis-Hadis Tentang Nikah Mut'ah.” Jurnal Tajdid 19(2).

Garwan, Muhammad Sakti. 2020. "Telaah Hermeneutika Dalam Kitab Ta'wil Mukhtalif Al-Hadits Karangan Ibn Qutaybah.” Jurnal Tajdid 19(2).

Goldziher, Ignaz. 1971. Muslim Studies, Terj. C.R. Barber Dan S.M. Sterm. New York: University of New York Press.

Idri. 2015. Epistimologi: Ilmu Pengetahuan, Ilmu Hadits, Dan Ilmu Hukum Islam. Jakarta: Kencana.

Idris, Abdul Fatah. 2016. "Memahami Kembali Pemaknaan Hadis Qudsi.” International Journal Ihya' 'Ulum Al-Din 18(2).

Ismail, Syuhudi. 1992. Metodologi Penelitian Hadits Nabi. Jakarta: Bulan Bintang.

Ismail, Syuhudi. 1995. Hadits Nabi Menurut Pembela, Pengingkar, Dan Pemalsunya. Jakarta: Gema Insani Press.

Qardhawi, Yusuf. 1999. Bagaimana Memahami Hadits Nabi, Terj. Muhammad AlBaqir. Bandung: Kharisma.

Rahman, Fathur. 2007. Ikhtisar Mushtolahah Al-Hadits. Bandung: PT. Al-Ma'rifah.

Setyawan, Cahya Edi. 2018. "Studi Hadis: Analisis Terhadap Pemikiran Schacht Dan A'zami." Jurnal Zawiyah 4(1).

Shalih, Subhi. 2007. Ulum Al-Hadits Wa Mushthalahuhu, Terj. Tim Pustaka Firdaus. Jakarta: Pustaka Firdaus.

Sumbullah, Umi. 2010. Kajian Kritis Ilmu Hadits. Malang: UIN-Maliki Press.

Suryadi. 2015. "Rekonstruksi Kritik Sanad Dan Matan Dalam Studi Hadis." Jurnal Esensia 16(2).

Tangngareng, Tasmin. 2016. "Metodhology of Hadith Content Criticism: A Study on the Thought of Salah Al-Din Bin Ahmad Al-Adlabi." Jurnal Esensia 17(1).

Ulum, Miftahul, and Ihsan. 2020. "Metode Penelitian Hadits Simultan Dalam Kitab Dhaif Al-Adab Al-Mufrad Lil Al-Imam Al-Bukhari Karya Nasiruddin Albani No 49 No Hadits 382/57 Tentang Memelihara Burung." Jurnal Al-Iman 4(2).

Ya'qub, Ali Mushtafa. 1995. Kritik Hadits. Surakarta: Pustaka Fidaus. Surakarta: Pustaka Firdaus.

Zainuddin. 2016. "Persoalan Otentitas Hadits: Bantahan Para Ulama Terhadap Pemikiran Ignaz Goldziher.” Qolamuna 1(2). 